slightly to the pit at soft ripe. We have judged 'Flordaglobe' as more attractive and superior in flavor to 'Flordaking'. Pits are mediumsmall and have a low (less than 'Flordaking') tendency to split.

Trees of 'Flordaglobe' are self-fertile, moderately vigorous, and productive. Leaves are medium in size, with reniform petiolar glands. Resistance of leaves and fruit to bacterial spot is high and about equal to 'Flor- daking'. Flowers are light pink and showy. Pollen is abundant and bright yellow.

\section{Availability}

Budwood has been released to commercial nurseries. Inquiries regarding availability of budwood can be directed to Florida Foundation Seed Producers, Inc., P.O. Box 309, Greenwood, FL 32443. Limited quantities of nonindexed budwood maybe obtained from the AREC-Monticello, Rt. 4, Box 4092, Monticello, FL 32344-9302.

\section{Literature Cited}

Andrews, C. P., W.B. Sherman, and P.M. Lyrene. 1979. 'Flordaking' peach. HortScience 14:81-82.

Weinberger, J.H. 1956. Prolonged dormancy trouble in peaches in the Southeast in relation to winter temperatures. Proc. Amer. Soc. Hort. Sci. $67: 107-112$.

\title{
'Charlee' Watermelon
}

\section{James M. Crall ${ }^{1}$. \\ Central Florida Research and Education Center, University of Florida, IFAS, 5336 University Avenue, Leesburg, FL 34748}

Additional index words. Citrullus lanatus, vegetable breeding, fusarium wilt resistance, anthracnose resistance, Fusarium oxyspomm, Colletotrichum lagenarium

The three major watermelon cultivars in Florida are 'Charleston Gray', 'Crimson Sweet', and 'Jubilee'. 'Charleston Gray' was introduced in 1954 and quickly was established as the leading cultivar for commercial production in Florida. 'Jubilee' and 'Crimson Sweet', both introduced' in 1963, also became important commercial cultivars in Florida and" other states.

In more recent years, 'Crimson Sweet' has become increasingly popular with growers because of its high yield and high level of resistance to fusarium wilt. Conversely, commercial plantings of 'Jubilee' and 'Charleston Gray' have decreased, principally -because of their lower level of resistance to wilt compared with 'Crimson Sweet'.

In 1971, a backcrossing program was begun to incorporate the high-level wilt resistance of 'Smoky lee', 'Texas W5', and 'Calhoun Gray' into 'Jubilee' and 'Charleston Gray'. Tests of backcross lines, conducted since 1978, showed that they were superior to the recurrent parent lines not only in resistance to fusarium wilt, but in many other characteristics' Selfing, with concomitant selection for both wilt resistance and desirable plant and fruit characters, was initiated in these backcross progenies in 1979. In subsequent years, both replicated and grower trials were conducted. 'Charlee', which was tested as SCWT 257 and Florida F83CE in 1984, 1985, and 1986 trials, is the first cultivar to be released from the backcrossing program.

Received for publication 21 July 1989. Florida Agricultural Experiment Station Journal Series no. R-00016. The cost of publishing this paper was defrayed in part by the payment of page charges. Under postal regulations, this paper therefore must be hereby marked advertisement solely to indicate this fact.

${ }^{1}$ Profcssor and Plant Pathologist. Leesburg, Fla., in 1984. Fla., in 1983 and 1984.

\section{Origin}

'Charlee' originated from a cross made in 1962 between 'Texas W5', which is highly resistant to fusarium wilt, and 'Charleston Gray' (Fig. 1). After several years of selfing, a *cross was made in 1971 with 'Calhoun Gray', which is also highly resistant to wilt. Following that cross, there were four crosses with USDA 51-27 ('Charleston Gray') and 11 selfings, the last four of which followed the final cross with USDA 51-27 in 1978. A seed increase in isolation $(\mathrm{F} 83 \mathrm{CE})$ of the final self-pollination (82M21-5,) was made in Fall 1983. Seed from this planting was fur- nished to the Florida Foundation Seed Producers, Inc., for increase and release as the new cultivar Charlee.

\section{Description}

Plants of 'Charlee' are vigorous and prolific, comparing favorably with 'Charleston Gray'. Fruits of both cultivars ripen in early midseason.

Fruits of 'Charlee' are similar to those of 'Charleston Gray' and 'Charleston Gray \#5' in size, shape, and weight (Table 1). They are remarkably uniform in both exterior and interior appearance (Fig. 2). Flesh is an attractive red, but not as intense as that of 'Dixielee'. Sugar content, expressed as percent soluble solids concentration of the juice, is not significantly different from 'Charleston Gray' or 'Charleston Gray \#5'. In organoleptic samplings, conducted as part of four replicated tests in 1983 and 1984, in which three or four experienced evaluators participated, flesh texture and flavor of 'Charlee' rated higher than those of 'Charleston Gray', 'Jubilee', 'Crimson Sweet'

Table 1. Characteristics of ripe fruits of 'Charlee', 'Charleston Gray', and 'Charleston Gray \#5' at

\begin{tabular}{lccc}
\hline \hline Characteristic & Charlee & Charleston Gray & Charleston Gray \#. \\
Range of weights $(\mathrm{kg})$ & & & \\
$\quad$ Maximum & 13.6 & 16.3 & 13.6 \\
$\quad$ Minimum & 8.6 & 7.7 & 9.1 \\
Mean wt $(\mathrm{kg})$ & 10.4 & 11.8 & 10.9 \\
Length $(\mathrm{cm})$ & 44.7 & 42.7 & 46.0 \\
Diameter $(\mathrm{cm})$ & 20.8 & 21.4 & 21.1 \\
Shape ratio $(\mathrm{L} / \mathrm{D})$ & 2.15 & 2.00 & 2.18 \\
Rind thickness $(\mathrm{mm})$ & 19.0 & 15.2 & 15.8 \\
Soluble solids concn $(\%)$ & 10.8 & 10.0 & 10.5 \\
Flesh color & Red & Red & Red
\end{tabular}

Table 2. Flesh texture and flavor of ripe fruits of 'Charlee' and several other cultivars at Leesburg,

\begin{tabular}{|c|c|c|c|c|c|c|c|c|}
\hline \multirow[b]{3}{*}{ Cultivar } & \multicolumn{8}{|c|}{ Trial $^{\mathbf{z}, \mathbf{y}}$} \\
\hline & \multicolumn{2}{|c|}{ Spring 1983} & \multicolumn{2}{|c|}{ Fall 1983} & \multicolumn{2}{|c|}{ Spring 1984} & \multicolumn{2}{|c|}{ Fall 1984} \\
\hline & Texture & Flavor & Texture & Flavor & Texture & Flavor & Texture & Flavor \\
\hline Charlee & $4.7 \mathrm{a}$ & $4.2 \mathrm{a}$ & $5.3 \mathrm{a}$ & $5.0 \mathrm{a}$ & $4.6 \mathrm{a}$ & $4.3 \mathrm{a}$ & $4.4 \mathrm{a}$ & $3.5 \mathrm{a}$ \\
\hline Jubilee & $\therefore 8 \mathrm{a}$ & $3.3 \mathrm{a}$ & $3.3 \mathrm{~b}$ & $3.8 \mathrm{~b}$ & $4.5 \mathrm{a}$ & $3.7 \mathrm{ab}$ & $3.4 \mathrm{ab}$ & $3.3 \mathrm{a}$ \\
\hline Charleston Gray & $3.5 \mathrm{a}$ & $3.5 \mathrm{a}$ & $3.5 \mathrm{~b}$ & $4.3 \mathrm{~b}$ & --. & $\therefore$ & $2.3 \mathrm{~b}$ & $2.8 \mathrm{a}$ \\
\hline Charlcston Gray \#5 & $\cdots$ & $\ldots$ & --- & $\cdots$ & $3.3 \mathrm{~b}$ & $2.7 \mathrm{c}$ & $3.0 \mathrm{ab}$ & $2.8 \mathrm{a}$ \\
\hline Crimson Sweet & -.. & --- & -.- &.- & $3.8 \mathrm{ab}$ & $3.3 \mathrm{bc}$ & -.- & -.- \\
\hline
\end{tabular}

${ }^{2}$ Scale for grading flesh texture and flavor: $0=$ poor, $6=$ excellent.

'Mean separation in columns by Duncan's multiple range test $P=0.05$. 


\begin{tabular}{lllllllllllll}
\hline 1062 & $1963-70$ & 1971 & 1974 & 1975 & 1976 & 1976 & 1977 & 1977 & 1978 & $1979-82$ & 1983 \\
\hline
\end{tabular}

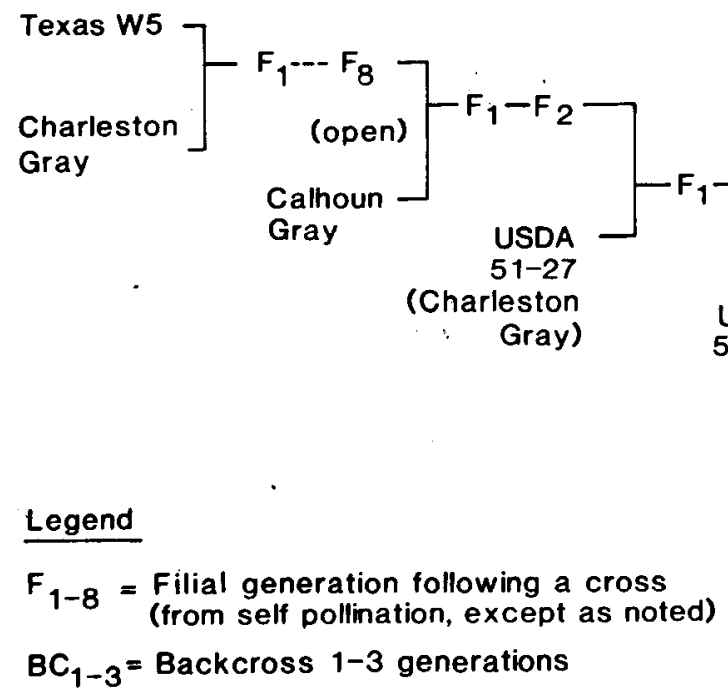

Fig. 1. Pedigree of 'Charlee' watermelon.

Table 3. Resistance to anthracnose (race 1) in 'Charlee' and other watermelon cultivars.

\begin{tabular}{lcc}
\hline \hline & $\begin{array}{c}\text { Anthracnose } \\
(\%)\end{array}$ & \begin{tabular}{c} 
infection \\
\cline { 2 - 3 } Cultivar
\end{tabular} \\
\cline { 2 - 3 } Greenhouse $^{z}$ & Field $^{y}$ \\
\hline Charlee & 0 & 0 \\
Charleston Gray & 0 & 0 \\
Charleston Gray \#5 & 41 & 20 \\
Charleston Gray \#6 & 90 & 100 \\
Calhoun Gray & 100 & 100 \\
New Hampshire & & \\
$\quad$ Midget & 100 & 100 \\
\hline
\end{tabular}

${ }^{2}$ Thirty plants per entry planted five per pot in six plots.

'Twenty plants per entry planted five per row in four rows.

Table 4. Resistance to fusarium wilt in 'Charlee' and other watermelon cultivars.

\begin{tabular}{lcr}
\hline \hline & \multicolumn{2}{c}{ Wilt (\%) $^{2}$} \\
\cline { 2 - 3 } Cultivar & Greenhouse $^{2}$ & Field $^{y}$ \\
\hline Charlee & 0 & 24 \\
Calhoun Gray & 33 & 12 \\
Charleston. Gray & & 54 \\
New Hampshire & 100 & 100 \\
$\quad$ Midget &
\end{tabular}

${ }^{2}$ Seedling wilt after $\approx 3$ weeks in fumigated soil infested at 600 propagules/g with soil inoculum of Fusarium oxysporum f. sp. niveum.

"Total wilt, including both seedlings and mature plants, determined by visual inspection with removal of completely wilted plants, on a weekly (after 12 weeks) or more-frequent (first 12 weeks) schedule. Soil infestation with causal organism of watermelon fusarium wilt was at a much higher level than ordinarily would be encountered in commercial production fields.

and 'Charleston Gray \#5' (Table 2). A firm, but not tough, flesh texture is characteristic of 'Charlee'. The rind is a solid gray-green with a faint net; rind thickness exceeded that of 'Charleston Gray' and 'Charleston Gray \#5' by 3 to $4 \mathrm{~mm}$. The rind is hard and tough and well-suited for shipping; pressures

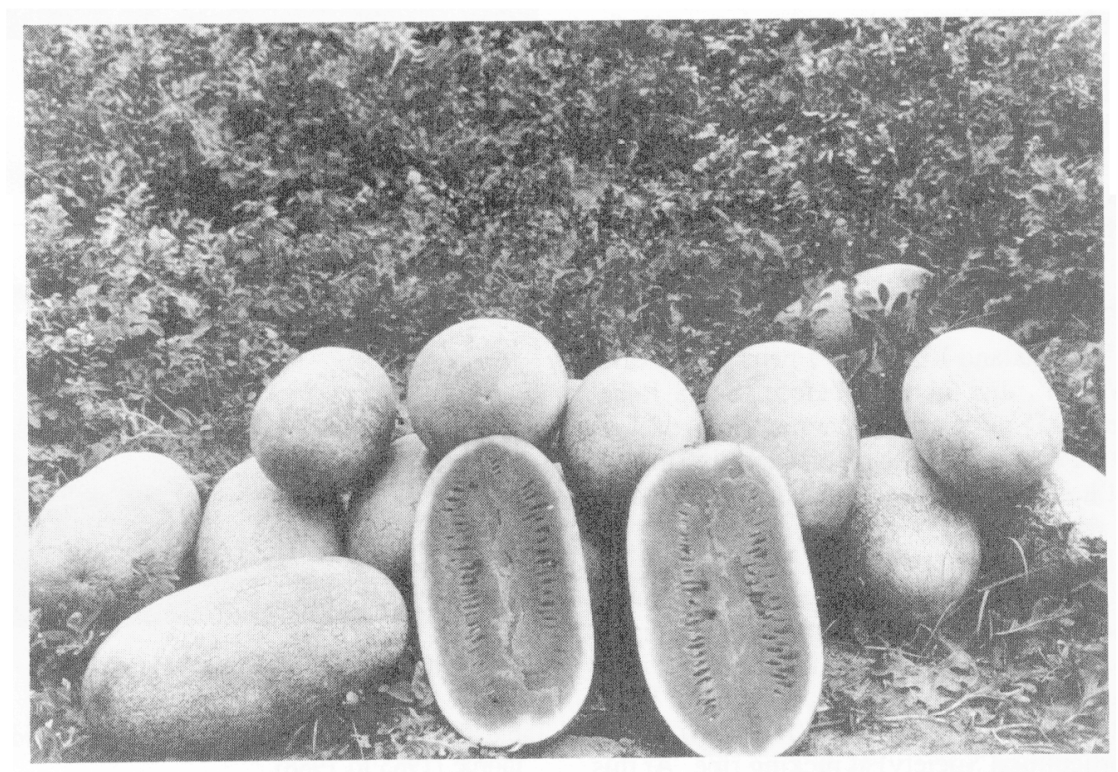

Fig. 2. 'Charlee' watermelon. Fruits from a $6.09 \times 7.62 \mathrm{~m}$ plot in replicated trial, Leesburg, Fla., 1983. Note striking uniformity in both size and shape of individual fruits.

over $13.6 \mathrm{kgf}(133 \mathrm{~N})$, as measured by a Chilton puncture tester (D. Ballauf Manufacturing, Washington, D. C.) with an ellipsoidal surface of $0.5 \mathrm{~cm}^{2}$, were required to puncture the rind at the midpoint of the fruit. This resistance was similar to the puncture resistance of the rinds of 'Charleston Gray', 'Calhoun Gray', 'Prince Charles', 'Crimson Sweet', and 'Jubilee'. Seeds are black, stippled, and medium-large.

'Charlee' is resistant to anthracnose (race 1) (Table 3) and fusarium wilt (races 0 and 1) (Table 4). Its wilt resistance is the same as that of 'Calhoun Gray', as contrasted with the moderate resistance of 'Charleston Gray' and the complete susceptibility of 'New Hampshire Midget'.
'Charlee' has performed well in both replicated and grower trials: it was the best of six lines in a Collier County grower test and has done well also in tests in Lake and Levy counties; it has consistently done well in the Southern Cooperative Watermelon Trials, being the top entry in the 1985 Replicated Trial.

\section{Availability}

Plant Variety Protection certification has been granted to 'Charlee'. Seeds are available from the sole seed producer, The Petoseed Company, Inc., P.O. B ox 4206, Saticoy,. CA 93004; or from several other seed companies sublicensed by them. 